\title{
Thin Films: Past, Present, Future
}

Ken Zweibel

National Renewable Energy Laboratory

Prepared for Progress in Photovoltaics, Special Issue on Thin Films (1995)

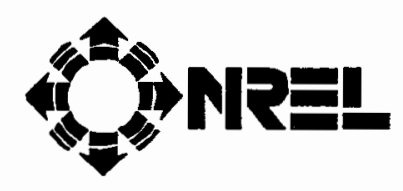

National Renewable Energy Laboratory 1617 Cole Boulevard Golden, Colorado 80401-3393

A national laboratory of the U.S. Department of Energy managed by Midwest Research Institute for the U.S. Department of Energy under Contract No. DE-AC36-83CH10093

April 1995 


\section{NOTICE}

This report was prepared as an account of work sponsored by an agency of the United States government. Neither the United States government nor any agency thereof, nor any of their employees, makes any warranty, express or implied, or assumes any legal liability or responsibility for the accuracy, completeness, or usefulness of any information, apparatus, product, or process disclosed, or represents that its use would not infringe privately owned rights. Reference herein to any specific commercial product, process, or senvice by trade name, trademark, manufacturer, or otherwise does not necessarily constitute or imply its endorsement, recommendation, or favoring by the United States government or any agency thereof. The views and opinions of authors expressed herein do not necessarily state or reflect those of the United States government or any agency thereof.

Available to DOE and DOE contractors from:

Office of Scientific and Technical Information (OSTI)

P.O. Box 62

Oak Ridge, TN 37831

Prices available by calling (615) 576-8401

Available to the public from:

National Technical Information Service (NTIS)

U.S. Department of Commerce

5285 Port Royal Road

Springfield, VA 22161

(703) $487-4650$ 


\title{
Thin Films: Past, Present, Future
}

\author{
Ken Zweibel \\ Thin Film Partnership Program \\ National Renewable Energy Laboratory \\ Golden, CO 80401 \\ 303-384-6441; 303-384-6430 (fax) \\ zweibelk@tcplink.nrel.gov
}

\section{The Idea of Low Cost PV}

The idea of thin films dates back to the inception of photovoltaics. It is an idea based on achieving truly low-cost photovoltaics appropriate for mass production. The key to the idea is the use of pennies worth of active materials. Since sunlight carries relatively little energy in comparison with combustion-based energy sources, photovoltaic (PV) modules must be cheap to produce energy that can be competitive. Thin films are presumed to be the answer to that low-cost requirement. But how cheap do they have to be? The following is an oversimplified analysis that allows some insight into this question.

If a PV module converts about $10 \%$ of incident sunlight into electricity, it will produce about 100 $\mathrm{W} / \mathrm{m}^{2}$. Actually, to produce that much electricity under operating conditions, with all temperaturedependent and other electronic losses, requires a module that is well over $10 \%$ efficient-more on this later. In one year, with average sunlight in the United States of about $1800 \mathrm{kWh} / \mathrm{m}^{2}$-yr for a fixed, flat-plate system in, for example, Kansas City, such a PV module would produce 180 $\mathrm{kWh} / \mathrm{m}^{2}$-yr. Over a 30 -year lifetime, it would produce about $5000 \mathrm{kWh} / \mathrm{m}^{2}$. How much money would it generate? If we assumed a revenue of 6 cents/kWh in the first year and an inflation rate of $3 \%$, revenue would grow to 14.6 cents $/ \mathrm{kWh}$ in the 30th year. Average revenue would be 10.3 cents/kWh, so total revenue would be about $\$ 515 / \mathrm{m}^{2}$.

If the same PV system cost $\$ 500 / \mathrm{m}^{2}$, it just barely pays for itself over its 30-year lifetime: The total reduction in electricity bills is $\$ 515$. Actually, this ignores operating and maintenance costs, which are, however, expected to be small. It also lumps costs such as inverters, which are usually stated as $\$ / \mathrm{kW}$, into the "\$/m2" category. This is okay for specific systems where the cost can be parameterized as " $\$ / \mathrm{m}^{2}$ " after the fact. The capital cost of the system will have to be smaller than $\$ 500 / \mathrm{m}^{2}$ to make it a worthwhile investment. To estimate how low the capital cost needs to be requires a way to compare the PV investment to other potential investments the consumer could make.

The concept of internal rate of return (IRR) provides the most straightforward way of making this comparison. Roughly speaking, the IRR can be defined as follows: Suppose the consumer has. money in a money market fund. He withdraws from this account the money needed to install the PV system. He deposits the amount of his energy savings back into the account as they accrue. The IRR is the interest rate on the money market account that leaves the consumer indifferent. That is, he will have the same amount of money after 30 years if he buys the PV system as he would have had if he had simply left all the money in the money market fund1. Obviously, the higher the equivalent interest rate, the better.

1 More formally, internal rate of return is defined (and calculated) as the discount rate which makes the present value of the stream of net cash flows involved in this investment equal to zero. 
Figure 1 shows how the rate of return changes as the capital cost is reduced from $\$ 500 / \mathrm{m}^{2}$ to $\$ 50 / \mathrm{m}^{2}$. (Note that at $10 \%$ system efficiency, these are equivalent to $\$ 5 / \mathrm{W}$ and $\$ 0.5 / \mathrm{W}$, respectively, at operating conditions.) The consumer pays no tax on the reduction in his energy bill. So the rate of retum on the PV investment should be compared to after tax yields on other investments 2 . One yardstick for after-tax return is the yield on municipal bonds. A 30-year, highquality, tax-free bond currently pays about $6 \%$ per year. To achieve this return at $10 \%$ system efficiency, the capital cost of the PV system would need to be $\$ 220 / \mathrm{m}^{2}$, or about $\$ 2.20$ per operating watt. At a system price of about $\$ 1.5 / \mathrm{W}$, the rate of return is about $10 \%$-a very attractive return, especially in after-tax dollars.

\section{Rate of Return as a Function of Capital Cost}

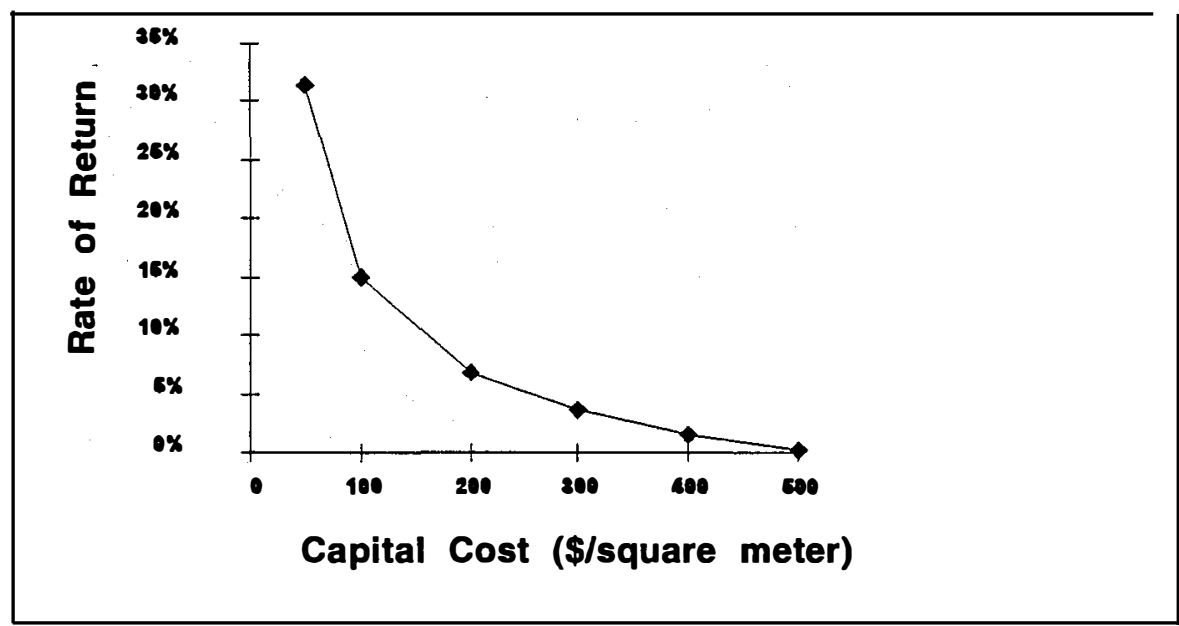

Figure 1. If an investor were to buy a PV system for various prices, the internal rate of return on that investment would be attractive (about $10 \%$ annually) at about $\$ 150 / \mathrm{m}^{2}$. This defines a goal for PV systems and, by implication, for thin-film modules. If the system efficiency were $10 \%$, the equivalent price in $\$ / \mathrm{W}$ would be about $\$ 1 / \mathrm{W}$ (operating, not peak watt).

Although this helps establish an ambitious long-term goal for thin-film PV (about $\$ 1.5 / \mathrm{W}$ for systems), it does not characterize well the interim situation. Fortunately, PV has been found useful by numerous consumers who value its electricity at greater than 6 cents/kWh. In fact, today's world PV market of about $80 \mathrm{MW} / y e a r$ is sold at prices closer to 6 times the goal- $\$ 10 / \mathrm{W}_{\mathrm{p}}$. Annual sales of systems are about $\$ 800$ million. Thus, although the ambitious long-term goal of PV is to be competitive in familiar markets such as for U.S. utilities, a series of interim markets of increasing magnitude will allow PV to evolve toward the long-term goal while generating considerable revenue and profits. Indeed, even in the United States, daytime electricity is more valuable than the average (because it meets higher daytime demands), implying that 6 cents/kWh" may be a conservative figure for revenue. Any discussion of the 6-cent $/ \mathrm{kWh}$ goal $/ \mathrm{market}$ must include these factors to be of value.

Let us return to the long-term goal to obtain a good perspective concerning the kind of progress needed. Today's PV modules are sold at a price of about $\$ 3.5-\$ 5 / \mathrm{W}_{\mathrm{p}}$. They are almost all waferbased crystalline silicon. Module efficiencies are about $10 \%-13 \%$. The price is then about

2 If the PV installation were built by a firm, say an independent power producer, several tax considerations would complicate the analysis. Somewhat surprisingly, the net effect of these tax considerations does not significantly change the after-tax IRR from what is shown in Figure 1. 
$\$ 400 / \mathrm{m}^{2}$. (Converting $\$ / \mathrm{W}_{\mathrm{p}}$ to $\$ / \mathrm{m}^{2}$ is simple: multiply the $\$ / \mathrm{W}_{\mathrm{p}}$ by $\mathrm{W}_{\mathrm{p}} / \mathrm{m}^{2}$ to get $\$ / \mathrm{W}_{\mathrm{p}} \cdot \mathrm{W}_{\mathrm{p}} / \mathrm{m}^{2}$ is simply the module efficiency times $1000 \mathrm{~W} / \mathrm{m}^{2}$. So for $11 \%$ modules at $\$ 4 / \mathrm{W}_{\mathrm{p}}$, the conversion is $\$ 4 / \mathrm{W}_{\mathrm{p}} \times 1000 \mathrm{~W} / \mathrm{m}^{2} \times 11 \%=\$ 440 / \mathrm{m}^{2}$.) If there is a $30 \%$ margin in this sale price, it would imply a manufacturing cost of about $\$ 300 / \mathrm{m}^{2}$ for today's $P V$. Similarly, the cost of the rest of the PV system is also large. The lowest-price PV systems are being installed for about $\$ 6 / \mathrm{W}_{\mathrm{p}}$. Perhaps balance-of-systems (BOS) prices are about $\$ 2-\$ 3 / \mathrm{W}_{\mathrm{p}}$, or about $\$ 250 / \mathrm{m}^{2}$. Despite its usefulness for other markets, PV would never reach 6 cents/kWh if BOS prices were to remain high. Fortunately, there are a number of reasons why BOS prices should fall significantly: today's systems are "oneof-a-kind" and incur very large one-time-only costs associated with design and installation; largescale, in-plant production of arrays should be possible for future large-scale systems; and none of the designs (mechanical or electronic) have yet been well optimized for PV. We must make an assumption that BOS costs will drop substantially to even discuss systems (modules and BOS) that can be competitive at about $\$ 150 / \mathrm{m}^{2}$ initial investment.

PV will be sold for quite some time into higher-value markets. Some of those markets (e.g., rural electrification) are about as large as the potential markets in developed countries. It is important to include this in planning by restating the PV goals to include these large, developing-country markets. Developing countries cannot easily find electricity at 6 cents/kWh, especially for dispersed uses. If one accepts a goal of 12 cents/kWh (plus inflation) for these markets, then a set of goals can be given, as in Table 1 .

Table 1. Goals to Achieve $>\mathbf{1 0 \%}$ Annual Return (Level of Initial Investment)

\begin{tabular}{|l|l|l|l|}
\hline & Today & @12 cents/kWh & @6 cents/kWh \\
\hline Thin-film modules & $400 \$ / \mathrm{m}^{2}($ wafer $\mathrm{Si})$ & $150 \$ / \mathrm{m}^{2}$ & $75 \$ / \mathrm{m}^{2}$ \\
\hline $\begin{array}{l}\text { BOS (including } \\
\text { "\$/kW" costs) }\end{array}$ & $250 \$ / \mathrm{m}^{2}$ & $150 \$ / \mathrm{m}^{2}$ & $75 \$ / \mathrm{m}^{2}$ \\
\hline
\end{tabular}

Assumes: 6 or 12 cents/kWh revenue; 10\% system efficiency (ac); average US sunlight; 30-year life

Note that the goals include more than price. In addition to the fact that thin-film modules must be priced at about $\$ 75 / \mathrm{m}^{2}$, they must produce electricity at an efficiency implying an ac system efficiency of $10 \%$, and they must lose less than $1 \%$ of their output annually for 30 years. The "low" system efficiency goal $(10 \%)$ is misleading. Normal loss mechanisms (operating temperature losses, wiring, module packing factor, dc-to-ac conversion, dust) reduce module performance by about $20 \%-30 \%$. A $10 \%$ system efficiency and a $30 \%$ operational loss implies a module of $14 \%$ efficiency under standard measurement conditions. Tradition has pegged the module goal for thin films at $15 \%$, which is as close as this kind of analysis can imply. Note also that some thin films may be less efficient but also less expensive, thus meeting the goals with different combinations of these key parameters. Indeed, various analyses (see below) suggest thin films can be made for under $\$ 50 / \mathrm{m}^{2}$, leaving some room for improving beyond the Table 1 goals.

Having established reasonable long-term goals for thin films, the question becomes: Can thin films meet these goals?

\section{The Performance Goal}

Perhaps the easiest goal to quantify is the performance goal. Figure 2 shows the world-record efficiencies of one-of-a-kind laboratory cells made from copper indium diselenide (CIS) and its alloys and from cadmium telluride (CdTe). Not shown are amorphous silicon cell effaciencies, ${ }^{, \infty} \cdots$ which lag behind (about 11\%, maximum for stabilized efficiencies). These one-of-a-kind cell 
results are by no means equivalent to achieving the same efficiencies in commercial products, but they are an important indicator of such a potential. But what is the relationship between small-area laboratory cells and large-sized modules?

\section{Polycrystalline Thin-Film Solar Cell Efficiencies}

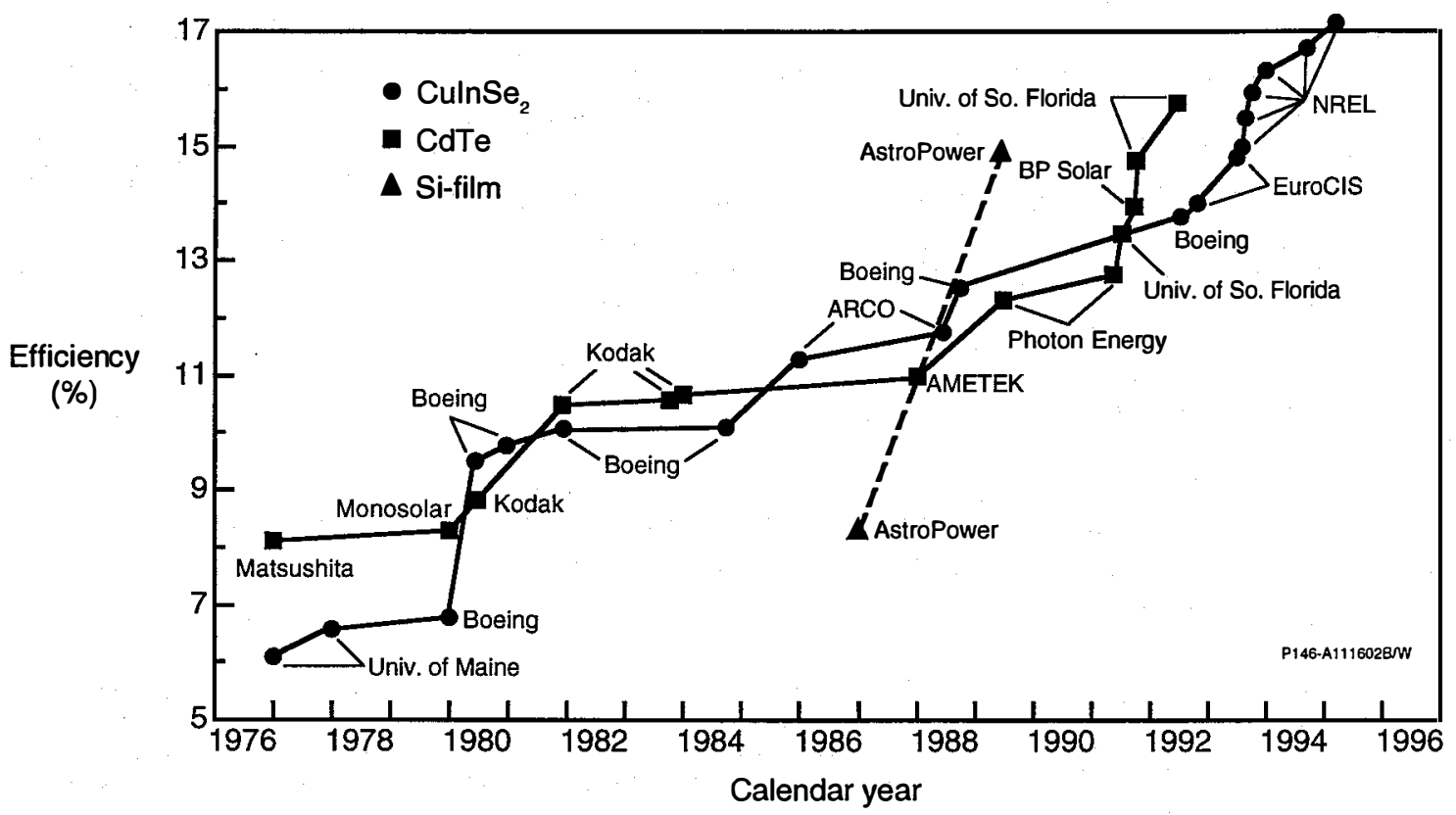

Figure 2. The best one-of-a-kind laboratory cell efficiencies for thin films now approach the best efficiencies produced by classic polycrystalline silicon. These achievements, once thought impossible, are the basis for expecting thin films to reach the performance goals needed for truly low cost.

In June 1988, ARCO Solar Inc. (Camarillo, CA; now Siemens Solar Industries) fabricated a oneof-a-kind CIS submodule (1- $\left.\mathrm{ft}^{2}\right)$ measured at the National Renewable Energy Laboratory (NREL) at $11.1 \%$ efficiency. At the same time, the world-record CIS cell efficiency was $12.5 \%$. In 1994, United Solar Systems Corporation (Troy, MI) fabricated a 10.2\%-efficient amorphous silicon submodule (1-ft 2 ) at a time when the record cell efficiency was only $11 \%$ for this material. The ratios of these efficiencies (cell/submodule) are 0.89 an 0.92 , respectively. Using a ratio of 0.9 , implies that it would require a cell of $16.6 \%$ efficiency to fabricate a $15 \%$ submodule. This efficiency $(16.6 \%)$ has been achieved by CIS-based cells and has nearly been achieved by CdTe cells.

The use of 0.9 somewhat misses the point, however. Commercial modules will always be less. efficient than one-of-a-kind submodules. They are larger (implying some uniformity-related loss) and must be made in large quantities (i.e., they are "average," not best). Some of these differences will be minimized as thin-film manufacturing technologies mature. To be careful, let us assume a further $10 \%$ gap between best cells and commercial modules. This suggests that laboratory cells of almost $19 \%$ would be needed to make $15 \%$ commercial modules. Cells of $17 \%$ efficiency (like those already made) would imply modules of about $13.6 \%$ efficiency. This is in the range needed to make the goal. Table 2 shows today's best one-of-a-kind thin-film modules. In many cases, the effort to scale up to product sizes (4-10 $\mathrm{ft}^{2}$ ) has been the recent focus, rather than efficiency champions at smaller, more tractable sizes (e.g., $1 \mathrm{ft}^{2}$ ). For this reason, module efficiencies trail best-cell efficiencies substantially. Companies recognize that an 8\%-10\%-efficient thin film will allow them to successfully compete in today's PV market, and that is their immediate motivation. 
Table 2. Best Thin-Film Modules

\begin{tabular}{|c|c|c|c|c|}
\hline Company & Material & Area $\left(\mathrm{cm}^{2}\right)$ & Efficiency (\%) & Power $(\mathrm{W})$ \\
\hline Solar Cells Inc. & CdTe & 7,200 & 8.4 & 60.3 \\
\hline Solar Cells Inc. & $\mathrm{CdTe}$ & 6,693 & 8.6 & 57.7 \\
\hline APS & $\mathrm{a}-\mathrm{Si} / \mathrm{a}-\mathrm{Si}$ & 11,522 & 4.6 & 53.0 \\
\hline Siemens Solar & CIS & 3,832 & $11.2^{* * * *}$ & 43.1 \\
\hline Siemens Solar & CIS & 3,859 & 10.2 & 39.3 \\
\hline BP Solar & CdTe & 4,540 & $8.4^{*}, * * *$ & 38.2 \\
\hline $\mathrm{ECD}$ & a-Si/a-Si/a-SiGe & 3,906 & 7.8 & 30.6 \\
\hline Golden Photon & $\mathrm{CdTe}$ & 3,528 & 7.7 & 27.5 \\
\hline Solarex & a-Si/a-SiGe & 3,432 & $7.8^{*}$ & 26.9 \\
\hline USSC & $\mathrm{a}-\mathrm{Si} / \mathrm{a}-\mathrm{Si}$ & 3,676 & 6.2 & 22.8 \\
\hline Fuji & $\mathrm{a}-\mathrm{Si} / \mathrm{a}-\mathrm{Si}$ & 1,200 & 8.9 & 10.7 \\
\hline Siemens Solar & CIS & 938 & 11.1 & 10.4 \\
\hline Matsushita Batt. & $\mathrm{CdTe}$ & 1,200 & $8.7^{*}$ & 10.0 \\
\hline USSC & $\begin{array}{l}\text { a-Si/a-SiGe/ } \\
\text { a-SiGe }\end{array}$ & 903 & 10.2 & 9.2 \\
\hline BP Solar & $\mathrm{CdTe}$ & 706 & $10.1^{*}$ & 7.1 \\
\hline
\end{tabular}

Note: After preliminary light-soaking for a-Si.

* Not measured at NREL ** Unencapsulated *** Not monolithic

Given the past history of achievements in thin-film cell efficiency, it seems that performance-if it can be transferred from lab cells to product-sized modules-will not be a "show stopper" for one or more thin-film technologies.

\section{The Lifetime Goal}

Outdoor performance must be dependable and of a duration approaching 30 years to rationalize the cost goals. PV has not been around much more than 30 years, but observation of PV systems suggests that the modules-almost all made using wafer-based silicon cells-are the most durable part of the system. Documented failure rates of only one per 10,000 per year are an important achievement by the wafer-silicon PV technology.

In sharp contrast, thin films have a checkered outdoor track record. The first thin films, made of copper sulfide, suffered from an electrochemical instability that led to degraded performance. Copper sulfide never became a significant thin film. The second commercial thin film-amorphous silicon (a-Si) - suffers from a serious degradation associated with (of all things) exposure to light. Called the Staebler-Wronski Effect, it results in about a $20 \%-40 \%$ degradation, unless checked by design modifications such as thinner intrinsic layers and the use of multijunctions. This degradation is what keeps a-Si efficiencies below those of other thin films. Combined with some start-up problems with encapsulation and quality control, the poor outdoor performance of a-Si products has-until recently--defined the bad reputation of thin films. 
Fortunately, many of these problems are behind us. Numerous minor problems (designing encapsulation, controlling the quality of the modules themselves) have been overcome as a-Si has matured. In addition, a major breakthrough came when it was observed that a-Si devices degrade to a reduced level and then do not degrade further. The absolute amount of degradation is somewhat dependent on the outdoor temperatures [1], being worse at lower operating temperatures. Advanced PV Systems (APS) has built and installed a 400-kW a-Si system at an installation in California called Photovoltaics for Utility-Scale Applications (PVUSA). This $\$ 5 / \mathrm{W}_{\mathrm{p}}$ system (perhaps the world's cheapest) has shown the typical behavior of a-Si modules (Figure 3): initial degradation, followed by stabilization and mild oscillation around the stabilization point. This behavior, called "stabilized efficiency" has taken the place of previous usages: now, all efficiencies quoted concerning a-Si are at lower, stabilized efficiencies, not at the false initial efficiencies. NREL has independently performed similar testing of APS a-Si modules and found the same phenomenon: an initial drop of about $25 \%$ followed by stabilization (Figure 4 ).

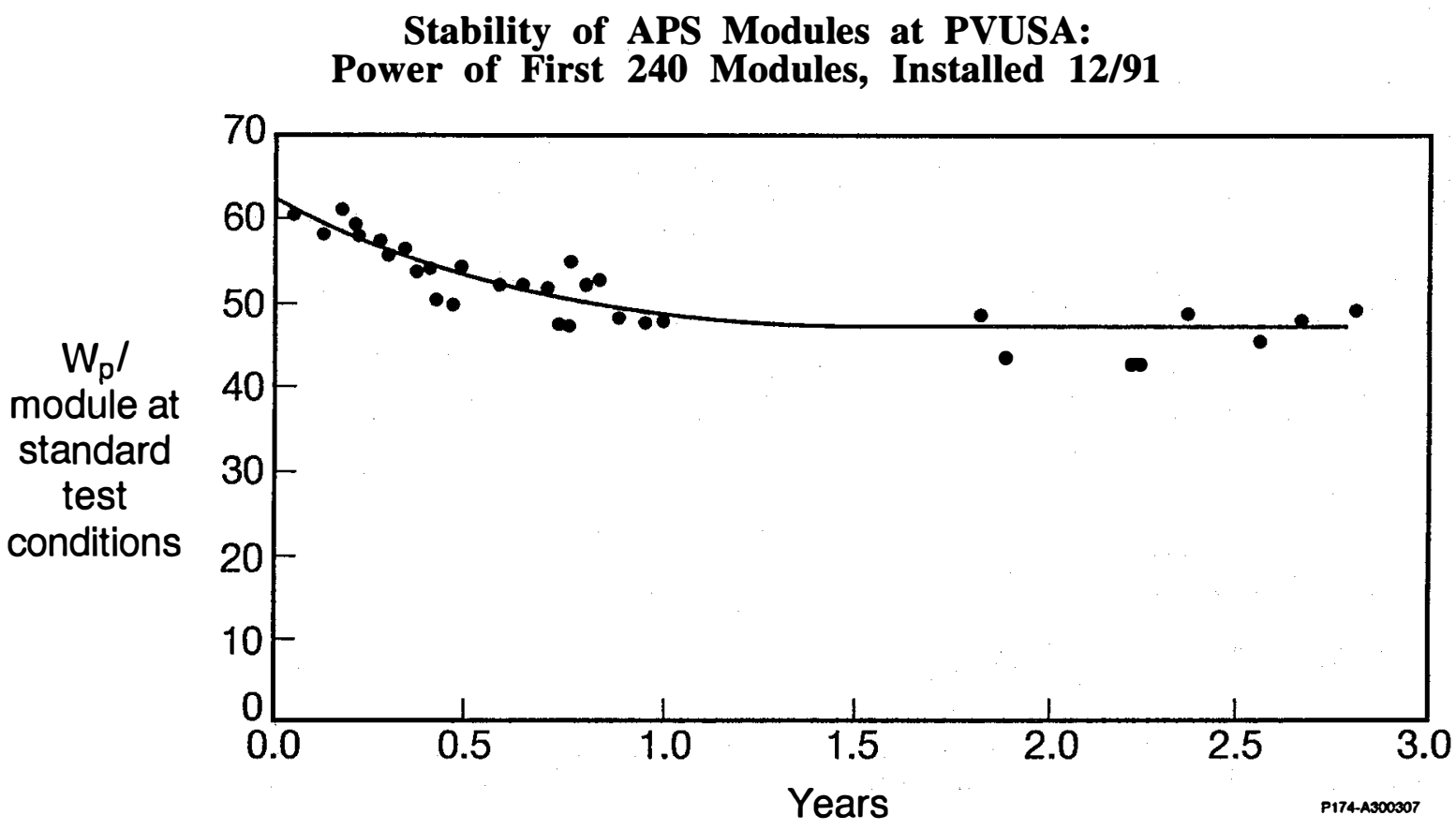

Figure 3. Amorphous silicon modules display a characteristic degradation that stops after an initial fall of about $20 \%$. An a-Si array made by APS and installed at PVUSA shows this typical behavior.

The other, newer thin films have problems as well. Like a-Si, they will no doubt suffer some startup problems (encapsulation, quality control). However, they do not have the Staebler-Wronski Effect to worry about, because they do not share the same "amorphous, hydrogenated" semiconductor nature as amorphous silicon - they are small-grained crystalline materials, more similar to crystalline silicon in that sense. In fact, initial outdoor tests of CIS-based and CdTe modules has been quite encouraging (Figures 5-7; CIS ARCO-SSI, SSI 1-kW; CdTe SCI).

NREL's data shows that some thin film modules have been made that appear to be stable over a period of 6 months to 6 years. This is a proof-of-concept that stability is possible. However, it is not the final word. To achieve true commercial stability, modules will have to be made with complete reproducibility so that such one-of-a-kind stability results become the norm for every module. Similarly, any hidden, longer-term issues-such as diffusion of impurities, the action of humidity, or other subtle degradations-will still require attention. One cannot be absolutely sure 
that new thin films have no catastrophic degradation mechanism lurking in the $n+1(<30)$ year. Only time will remove this natural concern.

\section{Outdoor Stability of APS Dual- and Single-Junction Amorphous Silicon} (Measured Outdoors under Prevailing Conditions, 9/30/92)

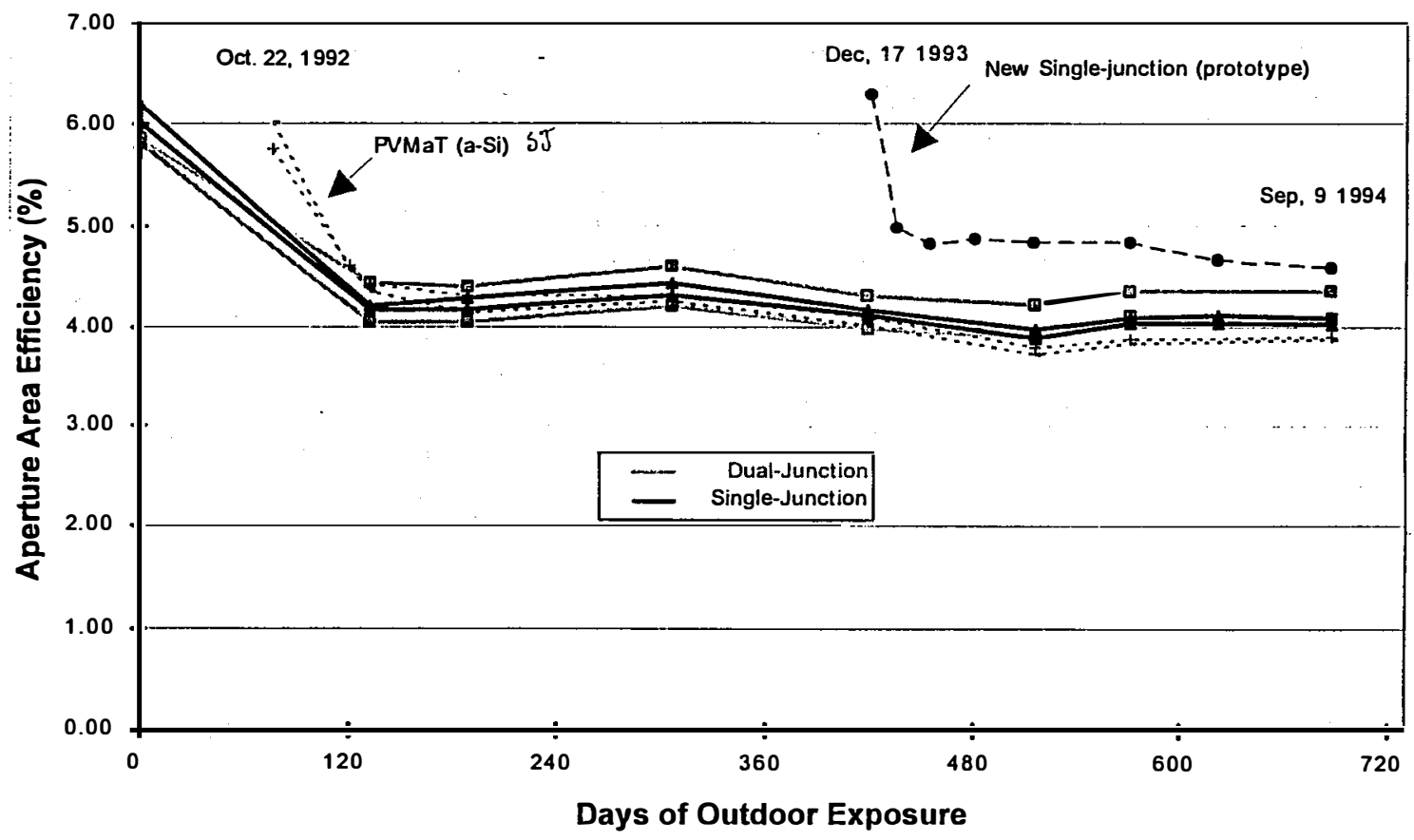

Figure 4. NREL has independently tested a number of APS modules in Colorado.They display the same behavior: initial degradation followed by stabilization.

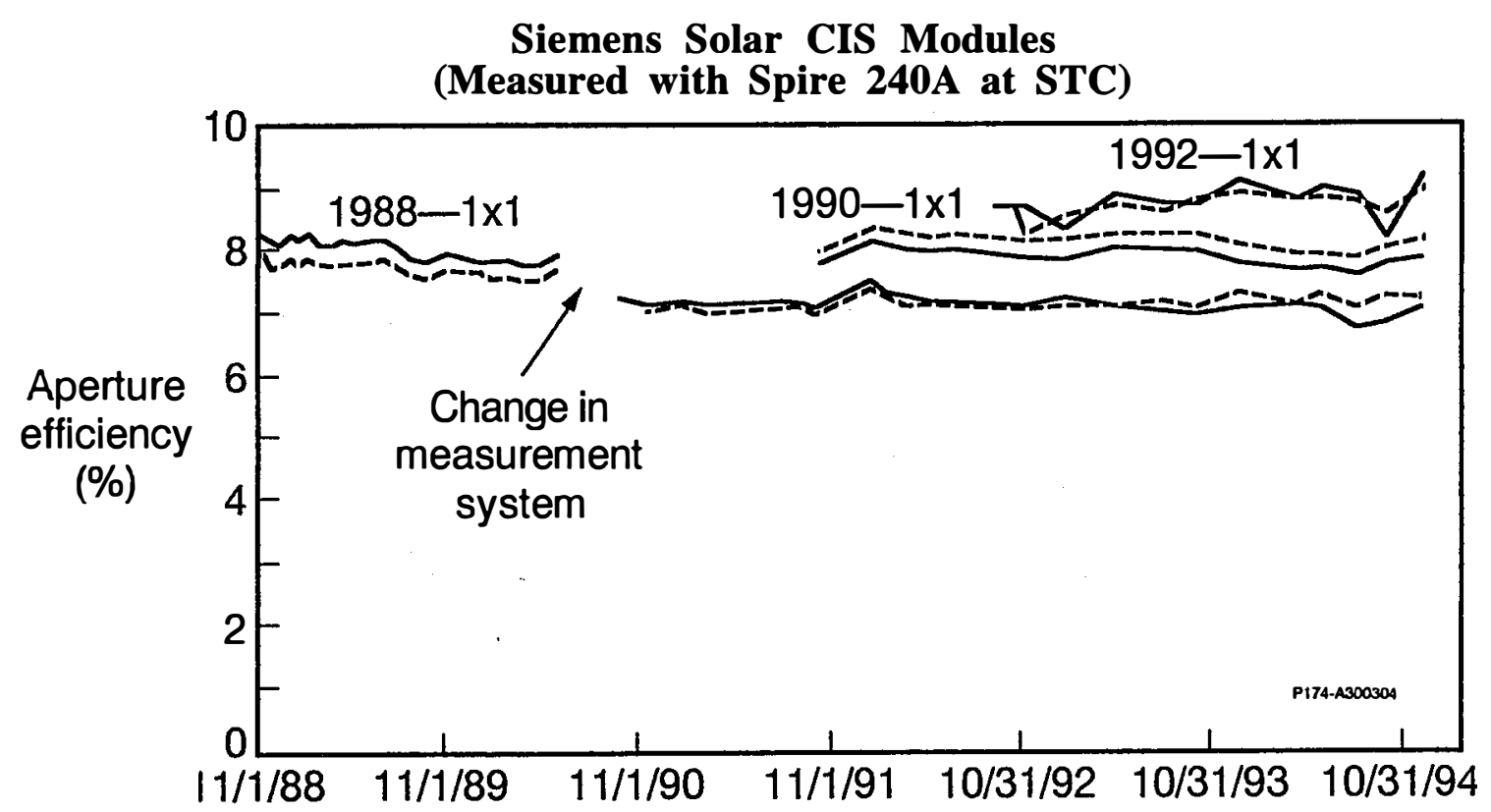

Figure 5. ARCO Solar (now Siemens Solar Industries) has sent CIS modules to NREL for testing over the past 6 years. These modules are remarkable for their stability over this extended period and are the benchmark for all other thin films. 
Siemens Solar CIS

Corrected Array Power versus Calendar Day

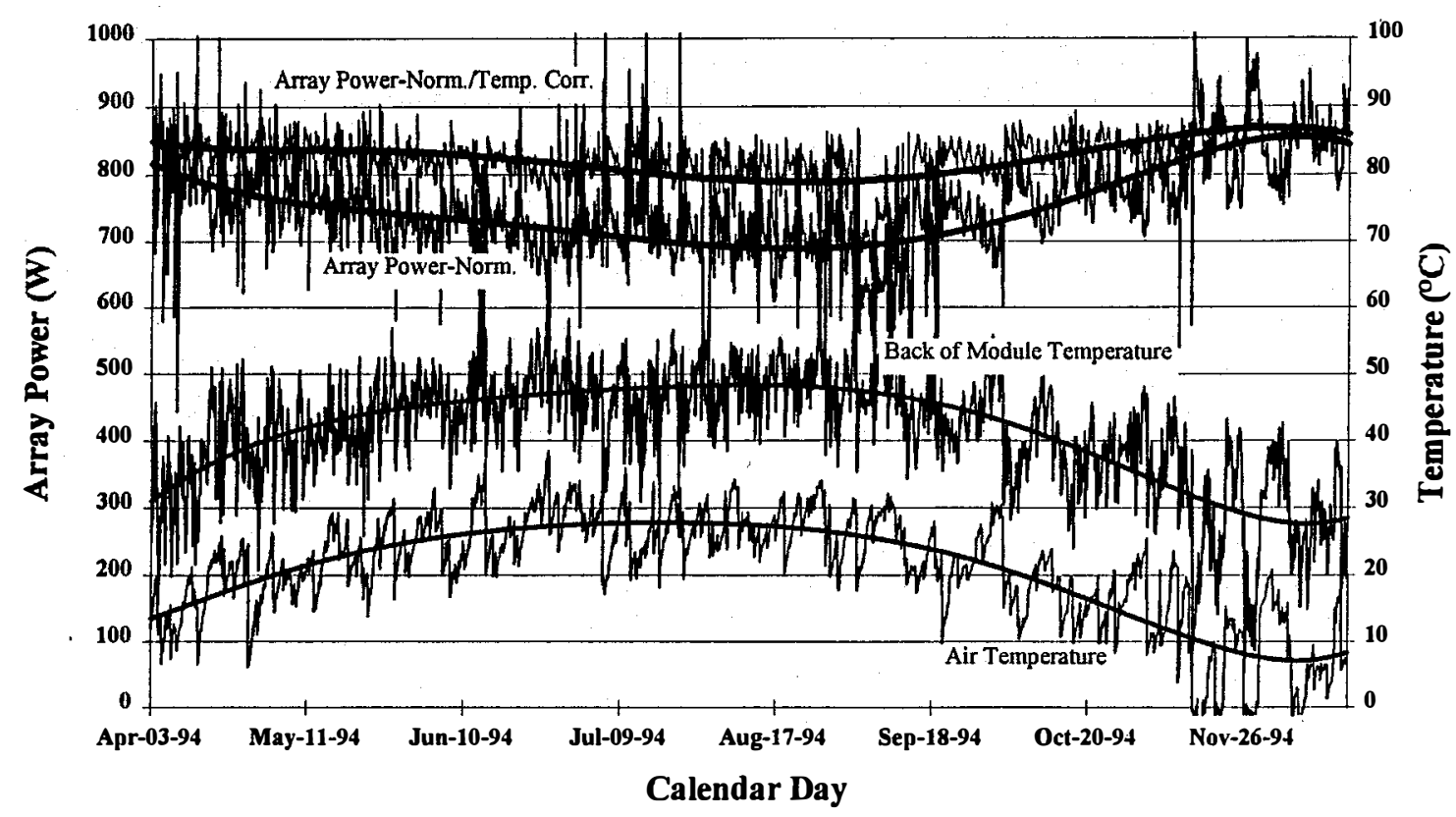

Figure 6. Siemens Solar installed a 1-kW CIS test array at NREL. The stable performance of the array has been consistent with previous module tests.

NREL Outdoor Test of SCI CdTe

dc Power vs. Temperature and Calendar Day

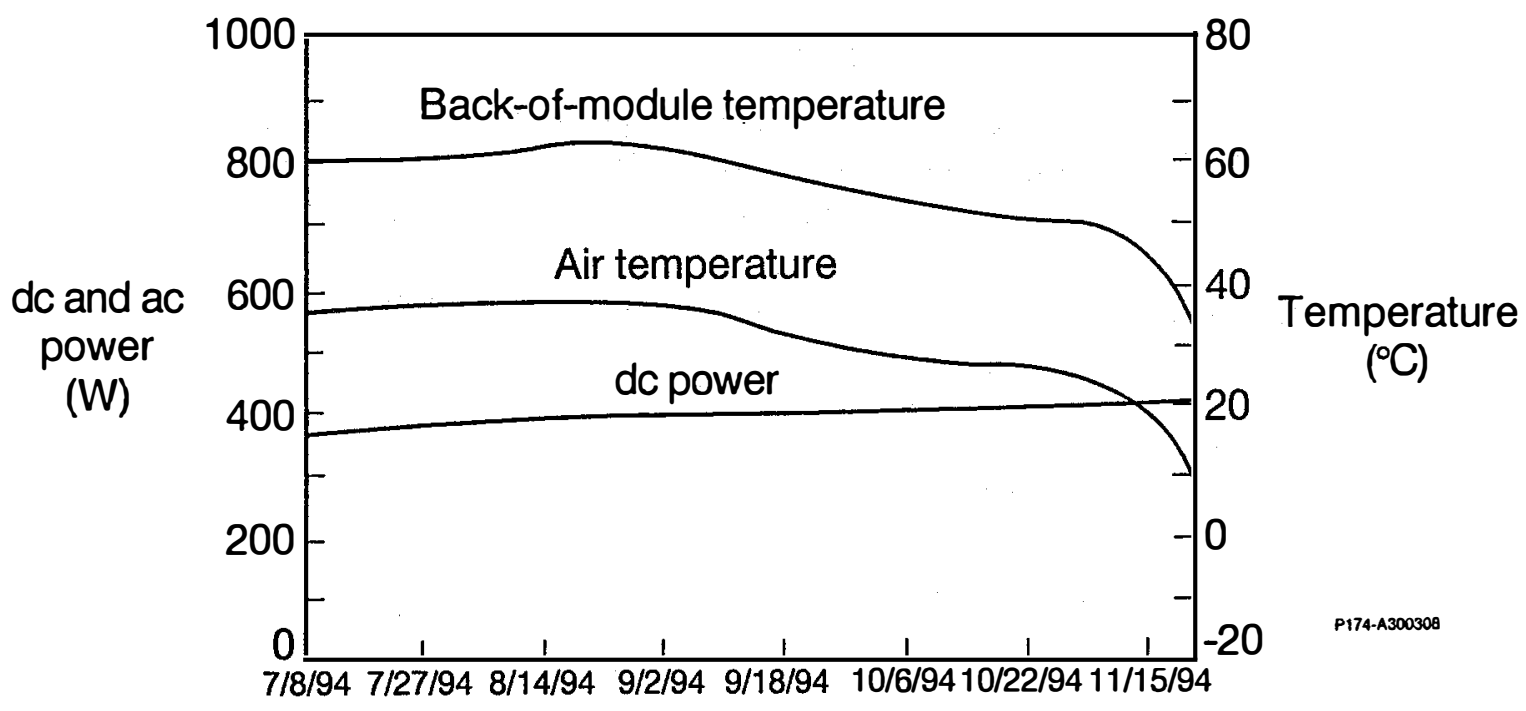

Figure 7. A number of CdTe modules have been tested that show excellent stability. Solar Cells Inc. has installed a 300-kW array at NREL, which has had perfect stability over the initial 6-month period.

\section{The Price Goal}

"Price" is a slippery item for a number of reasons:

(1) True manufacturing costs depend critically on yields and on step-by-step details such as 
materials utilization;

(2) Process complexities often show up only after the learning experiences of pilot and early, full-scale production;

(3) Innovations are continuously occurring, making last-year's bottleneck, next year's opportunity;

(4) Sales price is "what the market will bear" and is not fully reflective of costs; overhead varies by size of production and by markets; taxes and business strategies to reduce costs are impossible to fully characterize;

(5) Companies hold most or all such details confidential.

Because of this, it has been traditional to develop production cost models and to view any such models skeptically. A compilation of PV production cost projections [2-13] shows general agreement on the following:

- Thin films can be quite inexpensive. Costs (with overhead and profit) in the range of $\$ 40-\$ 80 / \mathrm{m}^{2}$ are reasonable long-term expectations.

- Materials costs are small: about $\$ 5-\$ 10 / \mathrm{m}^{2}$ for the active semiconductors and about another $\$ 10 / \mathrm{m}^{2}$ for the glass and encapsulation.

- Other important costs (energy input, equipment depreciation, labor) are about $\$ 10 / \mathrm{m}^{2}$ each, with additional costs for overhead and profit. For example, an original investment of $\$ 50$ million for equipment for a $100-\mathrm{MW}$ plant, amortized over 5 years, is close to $\$ 10 / \mathrm{m}^{2}$-yr. Using a 7-year amortization, it is about $\$ 7 / \mathrm{m}^{2}$.

- All costs depend critically on achieving high production yield ( $>90 \%$ final product) and high materials utilization in the materials-intensive steps (e.g., absorber layer deposition).

Production yield is the most sensitive issue. If yields fall below 50\%, economics are impossible (costs double). Somewhere in the 70\%-80\% range, yields move toward acceptability, but mature production plants should be in the $90 \%$ range to be able to approach the lower end (under $\$ 50 / \mathrm{m}^{2}$ ) of the cost goals.

Materials utilization will also become important as the technologies mature. Analyses of mature industries of various kinds suggest that the ultimate cost-limit is associated with materials costs. In a 2-micron-thick layer of $\mathrm{CuInSe}_{2}$, there are about $4 \mathrm{~g} / \mathrm{m}^{2}$ of indium (by far the most expensive element). At a cost of about $\$ 200 / \mathrm{kg}(\$ 0.2 / \mathrm{g})$, this is about $\$ 0.8 / \mathrm{m}^{2}$ at $100 \%$ utilization. At a more realistic $70 \%$ utilization, this would be an acceptable $\$ 1.15 / \mathrm{m}^{2}$. At $33 \%$ utilization, it would be up to $\$ 2.4 / \mathrm{m}^{2}$. At $10 \%$ use, it would be almost $\$ 10 / \mathrm{m}^{2}$. This example shows that there is some leeway in semiconductor costs, but such costs could become a problem if several of the materials are used poorly. Indeed, as some of the key materials (e.g., In, Te) are needed for larger production volumes, their costs may rise, tightening the allowable losses during production. Inplant recycling of these materials is a likely scenario for mature production.

The conclusion is clear: if yields are high (a technological issue) and materials use is fair to good (again, technology), thin films can be inexpensive. Thus, the essential issues driving the potential cost of thin films reside in the manufacturability area.

\section{The Thin-Film Technologies: Issues and Opportunities}

To understand the developmental issues of thin films, it is important to examine each individually. Each has a unique set of advantages and shortcomings in terms of their potential to reach the needed performance, reliability, and cost goals. For example, in some cases, manufacturability 
may imply optimizing existing processes/designs; in others, it may mean dropping existing components (sometimes critical ones) and starting over from the lab bench.

\section{Amorphous Silicon}

Amorphous silicon was viewed as the "only" thin film in the 1980s. By the end of that decade, and early in the 1990s, it was written off by many observers (and some investors). However, amorphous silicon technology has made good progress developing a very sophisticated solution-multijunction cells/modules - to most of its problems. Now it appears that commercial, multijunction a-Si modules could be in the 7\%-9\% efficiency range in the near term, and significant public announcements have been made by several companies (e.g., Solarex-Enron and United Solar) of 10-MW facilities to be built in the near future. This is a reminder of the well-known fact that all PV technologies go through difficult periods, and some (with enough investment) emerge with realistic chances of success.

However, there remain a number of serious problems with amorphous silicon technology. Today's best cell efficiencies (stable) are about $11 \%$. This is almost $50 \%$ lower than copper indium-gallium selenide (CIGS). But the difference is somewhat overstated by this bald comparison. Why?

Outdoors, CIGS loses about $20 \%$ of its output (due to operating temperature), while a-Si loses less than $10 \%$. Yet the problem of low efficiency (modules under $10 \%$ efficiency) could keep a-Si from ever dropping below $\$ 1 / \mathrm{W}_{\mathrm{p}}$ manufacturing cost. In the $\$ 1-\$ 2.5 / \mathrm{W}_{\mathrm{p}}$ range, a-Si could have a major impact on the PV marketplace. But its future will be limited if it cannot overcome the $10 \%$ efficiency "barrier" in power modules.

Today's multiband gap, multijunction designs are driven by the need to make thin layers to minimize the Staebler-Wronski Effect. Thus, key research efforts are focused on the component cells and their optimization. Despite these efforts, greater-than-incremental increases in cell efficiency have not occurred over the last 5 years. Indeed, almost all progress has been in using multijunction designs to make more-efficient modules. Fortunately, due to the relative maturity of a-Si manufacturing technology, this transition has been rapid. Within the a-Si community, there is little optimism that-without some breakthrough — cell efficiencies will move up to the $15 \%$ range.

One possible breakthrough is the "hot wire" approach being developed at NREL (see paper by Crandall, this issue). The hot-wire method was investigated by several previous research groups [14-17]. Early NREL results on moderate-efficiency devices show very promising stability (the absence of any light-induced degradation). However, the true stability of this new material is far from established, as is its potential to make more-efficient single- or multijunction cells. Without the establishment of these capabilities, we cannot say whether a major change is possible in a-Si technology. Even if "hot wire" succeeds, it would mean that new, large-scale processes for manufacture would have to be designed-a major challenge in itself.

Amorphous silicon fabrication methods are vacuum-based and fairly slow. This is not considered a serious near-term problem (cost advantage will exist even with current processing), but it is a midterm concern. Efforts are under way to speed up conventional glow-discharge, and the hot-wire technique is one example of a deposition technique that could be at least 10 times faster than existing glow-discharge.

The focus of near-term research in a-Si is on improving laboratory cell efficiency, whether by incremental improvements of multijunctions or by the development of a new a-Si technology that avoids the Staebler-Wronski Effect. Meanwhile, needed progress in manufacturing technology will go on in parallel to assure that costs continue to drop toward $\$ 1 / \mathrm{W}_{\mathrm{p}}$. 


\section{Cadmium Telluride}

The thin-film technology next closest to commercialization is based on cadmium telluride. Two U.S. companies have publicly announced manufacturing plants (Golden Photon Inc.[GPI] and Solar Cells Inc.), and the GPI facility is nearing completion (at 2-MW annual production). CdTe cell efficiencies are high (almost 16\% in the laboratory), but commercial module efficiencies are likely to be in the $6 \%-8 \%$ range in the first plants.

The problems with CdTe are somewhat different than those of a-Si. First, CdTe lacks a mature set of manufacturing options. Early attempts to manufacture it may yet encounter serious, unknown manufacturability problems. Almost no steps-from cadmium sulfide (CdS) deposition through cadmium chloride heat treatments-have been fully optimized. This is not to say that there is an obvious problem. Indeed, it is generally believed that CdTe is the easiest of the thin films to fabricate. More than a dozen methods have been used to make $10 \%$ cells. This allows the potential manufacturers to choose their least-cost method. The currently favored methods are high-rate evaporation (Solar Cells Inc.), spraying (Golden Photon Inc.), screen printing/sintering (Matsushita), and electrodeposition (BP Solar). Their rapid rates and/or low capital costs are a substantial advantage for CdTe. The point is that all of these potential advantages are unproven in actual manufacture, and possible start-up problems (such as those encountered by a-Si and other thin films) have not yet been encountered or overcome.

A subtle problem is that CdTe modules are much less efficient than CdTe cells. This gap is also apparent at the cell level, because the best cells are made by very few groups (U. South Florida and BP Solar are the only ones to make cells with more than $14 \%$ efficiency). The main capability implicit in these one-of-a-kind laboratory cells is the use of a thin n-CdS layer to form the junction with p-CdTe. This CdS layer must be thin enough to allow high energy light (above the 2.45-eV $\mathrm{CdS}$ band gap) to reach the junction. Yet, the CdS must be of adequate quality and coverage to make a good, high-voltage junction. Achieving these conflicting goals has been difficult in cells; it has yet to be done in modules. The ability to achieve high current and high voltage with thin CdS is the main research problem in CdTe technology.

Two other problem areas are of concern: stability and cadmium. With respect to stability, many CdTe cells and modules have been made with excellent stability and also with poor stability. This dichotomy - the fact that stability can be achieved, but many devices are unstable-deserves penetrating understanding. Is it quality control? Is it the use of contacts (such as gold, copper, or copper-gold) that are known to be unstable? What are the mechanisms of degradation-copper diffusion to the junction, oxidation at the contact, or humidity-driven corrosion at the contact? How long will the devices that work remain stable? The CdTe industry is moving rapidly towards commercial module introduction, yet these questions are unanswered. The situation is too reminiscent of early a-Si products in 1.985 .

Cadmium issues are another area of concern. Very little cadmium is used in CdTe modules-but enough to be of interest to health officials and policy makers [17-28]. It is as yet unknown whether commercial CdTe modules will be classified as hazardous waste, because some modules (BP Solar) have been reported to pass the appropriate U.S. Environmental Protection Agency tests (the TCLP) whereas others do not. Fluorescent lights (containing mercury) and computer screens (containing lead) are common examples of items that do not pass this test. In-plant waste-handling strategies at PV plants have been excellent, with suppliers such as ASARCO agreeing to take back (for re-smelting) any in-plant wastes. Engineering and management strategies to minimize worker hazards have been excellent as well. Sophisticated engineering controls have been put in place, and biomonitoring has been under way for years with no significant observed increases in worker exposure. Tests have been carried out to examine the toxicity of CdTe devices by ingestion (National Institutes of Health), and these have shown that the material is quite indigestible (and thus, does not normally enter the body by this route). Work is also under way to examine cost- 
effective means of assuring future product recycling of these modules. In summary, although a concern exists about cadmium in CdTe modules, it is viewed as manageable. Considering the advantages of PV in offsetting other sources of energy, the cadmium issue should be put in the same perspective as similar issues, e.g., mercury in fluorescent lights (where the environmental balance is considered favorable). Due to the nature of "thin film" CdTe modules, the use of cadmium in PV is always likely to remain a small fraction (under 10\%) of the world's use of cadmium - even if CdTe modules are one day able to provide a significant fraction (more than $10 \%$ ) of the world's electricity.

CdTe technology (1) suffers from the likelihood that near-term commercialization will encounter classic start-up issues (although such issues have not yet emerged); (2) has a stability problem, although stability is good in some cases; and (3) must raise the efficiency of modules toward those attained by the best cells, which will require head-on solution of processing challenges associated with using thin $\mathrm{CdS}$ in manufacturing. If these problems can be solved over the next 10 years, CdTe technology has a very good chance to achieve the long-term cost, performance, and stability goals. Viewed from this standpoint, it could be regarded as the leading thin film.

\section{Copper Indium Diselenide (and Related Alloys)}

Copper indium diselenide cells have reached $17 \%$ efficiency under standard test conditions. This means that the best CIS cell is approaching the best efficiency of a polycrystalline silicon cell $(17.8 \%)$. This is a strong proof-of-concept that thin films can perform well. However, CIS cells have major hurdles to overcome to be successful in the marketplace.

In 1988, the then ARCO Solar made a best-ever $11 \%$ CIS square-foot module. Almost 7 years later, this is still the most efficient thin film of its size, and CIS is still not commercially available. CIS manufacture ran into a set of start-up problems at ARCO Solar (now Siemens Solar) that put its future in jeopardy. They ranged from poor adhesion between the CIS and the bottom contact (molybdenum) to irreproducible deposition of the CIS. High yields at high efficiency could not be achieved. Commercialization was postponed while SSI went back to basics.

SSI addressed a number of important CIS issues during the last 5 years, trying to resolve manufacturing problems. They did so by redirecting their efforts to smaller submodules $\left(100-\mathrm{cm}^{2}\right.$, instead of their nearly 4000- $\mathrm{cm}^{2}$, CIS power modules). SSI reports that they have improved yields and raised efficiencies significantly. In the meantime, NREL learned how to make the best CIS cells in the world, reaching $17.1 \%$ efficiency in 1995 . We did so by including gallium and graded layers in our cells, achieving both improved morphology (larger grains) and better electronic properties. The NREL work built on previous groundbreaking work at Boeing (now discontinued) and by EuroCIS, the European consortium of universities.

The strength of CIS is also its problem: it is efficient because it is complex; but costs/manufacturability are impacted by complexity. CIS is really "CIGS"-or copper indiumgallium selenide, or even CIGSS (with sulfur). And layers of these complex compounds are made more complex by gradations designed for better cell performance. Fortunately, and against all intuition, some of the added complexity has actually led to greater flexibility in processing. Several groups (including NREL) report that adding gallium widens the window of compositional variation within which excellent cells can be made. This issue, the complexity of high-efficiency "CIGSS" cells, will have to be addressed by the manufacturers. Some of the work to explicate CIGS growth mechanisms, going on at NREL and elsewhere, should be of help.

Another serious concern is manufacturing cost. With several vacuum steps, CIS manufacture is seen as on the costly side among the thin films.There are few options for reducing the cost, because no nonvacuum approach (or even a high-rate vacuum approach) has been developed 
successfully. Materials use is also an issue, at least for the experimental processes. Indeed, there is no set process by which CIGS is expected to be made. This area-finalization of CIGS processes, followed by their optimization for cost-remains the key topic of CIS research.

In other ways, CIS has a strong basis. Unlike the other thin films, outdoor reliability has never been an issue. NREL data on CIS modules and a 1-kW system (SSI) have been exceptionally good, with no degradation by any modules, some outdoors for 6 years (Figures 5 and 6, above).

Good stability and proven efficiency make CIS a strong thin film. Commercialization is still problematic though because of manufacturability issues that run the gamut from fundamental properties through actually settling on a viable process. Long-term, the technology is as promising as any, and it is likely that the existing manufacturability issues will, one-by-one, give way to technological solutions.

\section{Film Silicon and Other Thin-Film Options}

Several groups have tried to combine the strong performance of crystalline silicon devices with the attractive economic advantages of thin-film manufacture-continuous, large-area processing. In fact, as the thickness of silicon is reduced, its material costs approach those of thin films. Except for the very high temperature of silicon processing, most attributes of the thin films can be achieved, if the crystalline silicon devices can perform as well as hoped and if they can be interconnected monolithically like thin films. Various U.S. companies (e.g., AstroPower) have taken this approach.

Success has not been easy. Thicker silicon cells on ceramic or foil substrates have been relatively efficient (cells near 15\%, modules near 9\%). But thin cells have not reached those levels. In fact, some of the physical aspects of silicon processing (the required diffusion lengths, the high temperatures, sensitivity to impurities) cause problems in making thin silicon cells on inexpensive (impure) substrates. There is significant work in Japan on some of these problems, both at Mitsubishi and Sanyo. But the future of large-area silicon films designed to meet $<\$ 1 / \mathrm{W}_{\mathrm{p}}$ goals remains uncertain.

The Swiss scientist Graetzel is known for an electrochemical device called the Graetzel cell, which is possibly the most elegantly simple PV device made. Using titanium dioxide (like that used for paint) and a long-lasting dye, a thin-film cell is made that has been reported to have reasonable (near 10\%) efficiency. However, like other electrochemical devices, it suffers from poor stability in use, losing its liquid components while under sunlight outdoors. Outdoor stability is measured in days, not years. Making higher efficiencies; achieving stability; demonstrating low cost in actual manufacturing are barriers that are familiar to all thin films - they are still very large barriers to the future of the Graetzel cell.

\section{Back to the Future}

The future of thin films looks strong. Despite serious obstacles, amorphous silicon has established itself as a viable competitor for wafer-based crystalline silicon devices. Once established in the marketplace, amorphous silicon is likely to make good progress and could even come to dominate the world PV market. Meanwhile, the next generation of thin films-CIS and CdTe-shows stronger technical performance (efficiency and stability) and similar or potentially lower cost. The goals for truly inexpensive PV are ambitious (15\% modules, 30 -year life, price under $\$ 75 / \mathrm{W}_{\mathrm{p}}$, or about $\$ 0.5 / \mathrm{W}_{\mathrm{p}}$ ), but thin films seem capable of reaching - even exceeding - these goals. The future is likely to be as checkered as the past, with technologies experiencing the harsh realities of early production and companies forced to endure losses that extend well past expectation. Other. technical plateaus will be suffered, but most issues will be overcome. The technical basis for thin 
films is solid; the accomplishments up to now have been in line with the technical basis and are likely to continue. Thin-film goals should be met, and by that means, low-price PV will become real. The key will be the resources and endurance needed to overcome technological challenges.

\section{Acknowledgement}

I would like to thank B. Kroposki, L. Mrig, T. Strand, and R. DeBlasio for the outdoor test data at NREL. In addition, I want to thank T. Bath's group at NREL-specifically, the services of D. Kline, who provided the IRR methodology and calculated the rates of return. This work was supported under DOE contract DE-AC36-83CH10093. Much of the progress described herein is also substantially the result of prior and ongoing DOE (and NREL) funding support for the leading U.S. thin-film companies and universities.

\section{References}

1. W. Luft, B. von Roedern, "Considerations for Light-Soaking of Amorphous Silicon PV Modules," First World Energy Conference on PV Energy Conversion, 1994.

2. T.W.F. Russell, B. N. Baron, R. E. Rocheleau, 1984, "Economics of Processing Thin-Film Solar Cells," J. Vac. Sci. Technology B2(4):840-844 (October-December 1984).

3. B. Jackson, September 1985, CdZnS/CuInSe 2 Module Design and Cost Assessment, SERI/TP-216-2633, Solar Energy Research Institute, Golden, CO (NTIS DE85016854).

4. P.V. Meyers, March 1990, Polycrystalline Cadmium Telluride $n$-i-p Solar Cells, SERI Subcontract Report, ZL-7-06031-2, Final Report, Solar Energy Research Institute.

5. V.K. Kapur, B. Basol, 1990, "Key Issues and Cost Estimates for the Fabrication of CIS PV Modules by the Two-Stage Process," Proceedings of the 21st IEEE PV Specialists Conference, I:467-470.

6. K. Zweibel and R. Mitchell, December 1989, "CuInSe 2 and CdTe Scale-Up for Manufacturing," SERI/TR-211-3571; NTIS \# DE89009503 (also in Advances in Solar Energy, 1990, K. Boer, ed., Plenum Press, NY).

7. J.H. Wohlgemuth, D. Whitehause, S. Wiedeman, A.W. Catalano, R. Oswald, (Solarex Corporation), December 1991, Final Report for PV Manufacturing Technology Phase I (Jan.April 1991), NREL/TP-214-4483 (DE92001166).

8. M. Izu (Energy Conversion Devices, Inc.), March 1992, Final Report for PV Manufacturing Technology Phase I (Jan.-April 1991), NREL/TP-214-4579 (DE92001199).

9. S. Albright (Photon Energy Inc.), November 1991, Final Report for PV Manufacturing Technology Phase I (Jan.-April 1991), NREL/TP-214-4569 (DE91015032).

10. B.J. Stanbery (Boeing Aerospace \& Electronics), November 1991, Final Report for PV Manufacturing Technology Phase I (Jan.-April 1991), NREL/TP-214-4606 (DE92001176).

11. T. Jester (Siemens Solar Industries), November 1991, Final Report for PV Manufacturing Technology Phase I (Jan.-April 1991), NREL/TP-214-4481 (DE92001153).

12. J. Brown (Solar Cells Inc.), November 1991, Final Report for PV Manufacturing Technology Phase I (Jan.-April 1991), NREL/TP-214-4478 (DE91015027). 
13. S. Wagner, D. E. Carlson, "Amorphous Silicon Solar Cells," 10th E.C. Photovoltaic Solar Energy Conference, 1991, pp. 1179-1183, Kluwer Academic Publ.

14. H. Wiesman, A. K. Ghosh, T. McMahon, M. Strongin, 1979, "a-Si: H produced by HighTemperature Thermal Decomposition of Silane," J. Appl. Phys. 50(5), 3752-3754.

15. Hideki Matsumura, 1986, "Catalytic Chemical Vapor Deposition (CTL-CVD) Method Producing High-Quality Hydrogenated Amorphous Silicon," Japanese Journal of Applied Physics, v. 25 , n. 12, L949-L951.

16. J. Doyle, R. Robertson, G. H. Lin, M. Z.He, A. Gallagher, 1988, "Production of HighQuality Amorphous Silicon Films by Evaporative Silane Surface Decomposition," J. Appl. Phys. 64(6), 3215-3223.

17. E.A. Alsema, B.C.W. van Engelenburg, 1992, "Environmental Risks of CdTe and CIS Solar Cell Modules," 11th European Solar Energy Conference, Montreux, October 12-16, 1992 (in press).

18. P.D. Moskowitz, V.M. Fthenakis, 1990, “Toxic Materials Released from PV Modules during Fires: Health Risks," Solar Cells.

19. P.D. Moskowitz, V.M. Fthenakis, L.D. Hamilton, J.C. Lee, 1987, "Public Health Issues in PV Energy Systems: An Overview of Concerns," Solar Cells 19:287-299.

20. P.D. Moskowitz, V.M. Fthenakis, K. Zweibel, 1990, "Health and Safety Issues Related to the Production, Use, and Disposal of Cd-Based PV Modules," 21st IEEE PV Specialists Conference, Orlando, FL, May 21-25, 1990.

21. P.D. Moskowitz, L. D. Hamilton, S. C. Morris, K. M. Novak, M. D. Rowe, 1990, Photovoltaic Energy Technologies: Health and Environmental Effects Document, Brookhaven National Laboratory, Upton, NY, BNL-51284.

22. P.D. Moskowitz, K. Zweibel (eds), Recycling of Cadmium and Selenium from PV Modules and Manufacturing Wastes: A Workshop Report, March 11-2, 1992, Golden Colorado, BNL 47787, Brookhaven National Laboratory.

23. P.D. Moskowitz, K. Zweibel, V.M. Fthenakis, 1990, Health, Safety, and Environmental Issues Relating to Cadmium Usage in PV Energy Systems, SERITR-21 1-3621 (DE90000310).

24. R.L. San Martin, "Environmental Emissions from Energy Technology Systems: The Total Fuel Cycle," April 1989, U.S. Department of Energy.

25. W.K. Tolley, G.R. Palmer, 1991, "Recovering Cadmium and Tellurium from CdTe Manufacturing Scrap," Bureau of Mines, Salt Lake City, Utah, for 1991 AIME Annual Meeting, New Orleans, LA, Feb. 1991.

26. J.L. Stone, E. Witt, R. McConnell, T. Flaim, 17th IEEE PV Specialists Conference, 1984, p. 1178 .

27. K. Zweibel, T.L. Chu, "Cadmium Telluride Photovoltaics," Chapter 16 in Advances in Solar Energy, v. 8, M. Prince (ed), American Solar Energy Society, Boulder, CO, 1993.

28. Meridian Corporation, 1989, Energy System Emissions and Material Requirements, prepared for U.S. Department of Energy, Office of Renewable Energy. 